\title{
1. The concept of private law
}

\subsection{WHAT IS PRIVATE LAW?}

What is private law? The question of the concept of private law is prima facie easy to answer. Private law deals with the rights and duties of individuals (including other private actors such as companies). ${ }^{1}$ As such, it invades all domains of our lives, from birth to death, at work and leisure, family and business, socially and economically. We do our daily shopping, we buy things, rent homes, book holidays, in real life or digitally. We start a family, make a will, accept a job offer, start a new business, hire staff. In other situations we may be less lucky. Things happen: we get involved in a traffic accident, cars crash, people get injured, or less dramatically: we may get involved in a conflict with our neighbours, or we may forget to close a cellar hatch and someone falls in. In all these instances our actions - both individually and socially - are subject to private law and thus have legal consequences. Most of the time private law works without us being aware of it - regulating our lives invisibly - like some kind of cement of civil society. Only occasionally - for example if a dispute arises - do we start asking ourselves questions on our mutual rights and duties. We may turn to a lawyer, who advises us on our legal position. Ultimately we may seek recourse in a court of law, or we may find ourselves there as a defendant.

Then the question arises as to where to find private law. First, we have legislation of course, although its role may vary in different legal systems. Civil law systems are characterized by the availability of a codification of private law, like the Code Civil (in France) or the Bürgerliches Gesetzbuch (in Germany). Common law systems lack the codifications of civil law, but instead rely upon a long tradition of case law developed by the courts, to be applied as precedents in future cases. ${ }^{2}$ Although the difference is important in principle, it is less decisive in practice. Common law systems have separate

1 Jan M. Smits, Advanced Introduction to Private Law (Cheltenham/Northampton: Edward Elgar Publishing, 2017) 1.

2 Rupert Cross, Precedent in English Law (2nd edition, Oxford: Clarendon Press, 1968). Cass A. Sunstein, One Case at a Time, Judicial Minimalism on the Supreme Court (Cambridge, Mass.: Harvard University Press, 1999). 
pieces of legislation as well, and in civil law systems the codified rules have to be interpreted by the courts in individual cases. ${ }^{3}$ So next to legislation, judicial rulings constitute another source of private law, both in common law and in civil law systems. Since the domain of private law is so extensive, it is impossible to regulate everything in advance, with the result that enacted rules and regulations are always specified in particular cases ex post facto by the courts. Another consequence is that private law - both in common law and in civil law systems - is always open to social norms, moral values, and usages or customs. Codifications often anticipate by using open norms such as the norm that parties are to act in good faith ('reasonableness and fairness'), or the standard of 'the man on the Clapham omnibus' ('bonus pater familias'). These unwritten rules and norms constitute the third source of private law.

Fourthly, we have to extend our horizons beyond the borders of our national jurisdictions. Some sources of private law have a transnational origin, whether it be in the form of more encompassing legal systems (like the European Union, or the Council of Europe) or in the form of treaties (like the Convention on Contracts for the International Sale of Goods 1980). Our private law systems have become multilayered systems in which sources of varying origin and scope regulate individual and social relations, with often varying legal consequences. ${ }^{4}$ Finally, an important source of private law is the regulations without authoritative status - so-called 'soft law' - such as Restatements of the Law in the US, the Unidroit Principles of International Commercial Contracts (PICC) on a global scale, or the Principles of European Contract Law (PECL), the Principles of European Tort Law (PETL) and the Draft Common Frame of Reference in the European Union. All in all, the sources of private law seem as diverse as the domain of private law itself. This diversity is a real challenge for legal scholarship.

\subsection{TWO PARADIGMS OF LEGAL SCHOLARSHIP}

What is characteristic for private law? How is it to be understood or studied? These simple questions split the academic legal community in to (again) a diversity of opinions, which, however, can be merged into two opposing camps: the traditional dogmatic approach and the functionalist social science

3 H. Patrick Glenn, Legal Traditions of the World: Sustainable Diversity in Law (5th edition, Oxford: Oxford University Press, 2014) Chs 5 and 7. Mathias Siems, Comparative Law ( $2^{\text {nd }}$ edition, Cambridge: Cambridge University Press 2018) 50-84.

4 Paul Schiff Birman, Managing Legal Pluralism: A Jurisprudence of Law beyond Borders (Cambridge: Cambridge University Press 2012), https://scholarship.law.gwu .edu/cgi/viewcontent.cgi? article $=1022 \&$ context $=$ faculty_publications, accessed 23 March 2021. 
approach of private law. The dogmatic approach has the oldest papers, it goes back to the reception of the ius commune in the early Middle Ages, and thus to classical Roman law. The dogmatic approach has always had a strong connection with legal practice, engaged in the daily business of dispute settlement and societal problem-solving. Put simply, its methodology comes down to the description, analysis and systematization of private law, as it has been developed in legal practice. ${ }^{5}$ Since private law is embedded in texts, legal dogmatics sees itself primarily as a textual discipline, dedicated to the interpretation of authoritative texts (whether legislation or judicial rulings) and to the argumentation of legal opinions (whether one-sided or deliberative). Legal dogmatics is at its core an interpretative-argumentative discipline, dedicated to society and private law itself. ${ }^{6}$ As such, it has been extremely successful. From the days of the Roman law to the present-day legal practice, legal dogmatics has proved to play an essential role in the interplay between private law practice and its scholarly research, as well as their development in law firms, courts and universities.

However, as with any other discipline, legal dogmatics has its limitations. To demonstrate this, we examine the theory of one of its most elaborate theoreticians: Ernest Weinrib. According to Weinrib, private law is to be grasped only from within and not in terms of the extrinsic functions it is supposed to serve. Compare it with love: love does not serve any purpose, it is its own end. Private law is like love in this respect. ${ }^{7}$ As such, private law can be characterized conceptually and institutionally. Conceptually, it embodies a regime of correlative rights and duties between parties. Concepts like 'contract' and 'tort' - if applicable - establish a normative pattern between parties. Institutionally, it involves an action by a plaintiff against a defendant in a process of adjudication that retroactively establishes the rights and duties of the parties. The judicial intervention not only solves the dispute between the parties, it also establishes their mutual rights and duties. Private law is essentially a normative practice, establishing the rights and duties in the bilateral relations between parties in an ever more coherent manner. In the classic

5 That's why it is called 'legal dogmatics', since valid private law is the dogma of legal scholarship. For a more sophisticated characterization, see Jan M. Smits, 'What is legal doctrine? On the aims and methods of legal-dogmatic research' in Rob van Gestel, Hans-W. Micklitz and Edward L. Rubin (eds), Rethinking Legal Scholarship, A Transatlantic Dialogue (Cambridge: Cambridge University Press 2017) 207-229.

6 That's why it is often presented as 'legal hermeneutics', since hermeneutics is the discipline of the interpretation of texts.

7 Ernest J. Weinrib, The Idea of Private Law (Cambridge, Mass.: Harvard University Press, 2012) 6. 
phrase of common law lawyers: the law can work itself pure. ${ }^{8}$ What does this imply for legal doctrine? It implies that legal dogmatics is the continuous effort to grasp the relation between parties in terms of the system that regulates these relations. This requires reflection on legal practice; its characteristic ways of thinking, speaking and acting. For legal education this implies a curriculum in which students are not only familiarized with the concepts and institutions of private law, but also with the characteristic ways of interpreting and reasoning in private law. However, there is a self-referential element in this programme. Concepts like 'contract' and 'tort', for example, are at the same time the object and the product of legal doctrine. If legal dogmatics works with the same concepts and norms that are the object of its study, it is eventually a self-understanding enterprise. ${ }^{9}$

At this point the doctrinal approach meets two objections. The first objection is that private law itself cannot be just pointless, it has to have some goal or purpose. Any introduction to private law starts by identifying private law's purposes, such as constituting civil society or peaceful dispute settlement. ${ }^{10}$ 'The final cause of law', Cardozo wrote, 'is the welfare of society.'11 Starting from the realism of Cardozo and others, Richard Posner developed a pragmatic perspective on law, characterized by a societal, future-oriented, anti-dogmatic perspective. ${ }^{12}$ On this pragmatic foundation he has built a methodology of Law and Economics, which views private law as a system to enhance social welfare and to reduce social costs. In this approach legal rules are to be analysed in instrumental terms, as an effective and efficient means to contribute to the overarching goals. Of course, this requires a methodology other than text analysis. This brings us to the second objection to legal dogmatics, namely that its textual methods are not up to standard any more and do not fit in modern social sciences. If private law in its economic context is the subject of study, we need economic and thus empirical methods. Law and Economics does in fact involve the application of economic theory to legal questions, such as the regulation of accidents by means of tort law, or of monopolies by means of antitrust law. This kind of analysis may provide arguments for the change of legal regulations to make them more effective and efficient. ${ }^{13}$ As such, it has

Omychund v. Barker [1744] 26 Eng. Rep. 15, 23.

Weinrib (n. 7) 14.

10 Tony Honoré, About Law: An Introduction (Oxford: Clarendon Press, 1995) 1-2.

11 Benjamin N. Cardozo, The Nature of the Judicial Process (New Haven, Conn.: Yale University Press, 1921).

12 Richard A. Posner, Overcoming Law (Cambridge, Mass.: Harvard University Press, 1995) 33-80.

13 Richard A. Posner, Law and Literature, A Misunderstood Relation (Cambridge, Mass.: Harvard University Press, 1988) 1. 
been very successful, in policymaking, as a research programme, and in legal education. In universities across the world - starting with Chicago Law School - it influenced legal curricula deeply. Moreover, it paved the way for other 'Law \& ...' approaches, such as Law and Sociology, Psychology, Literature, etcetera. In fact, it undermined the monopoly of the dogmatic approach, changed the landscape of legal scholarship and established a growing gap between the universities and legal practice. ${ }^{14}$

The debate between legal dogmatics and its functional opponents has been fierce. Dogmatic scholars have accused the functionalists of imposing goals and purposes on private law that are alien to its nature (such as welfare maximalization and cost reduction). This does not explain the nature of private law, so the argument goes, it reduces it to something else. The functionalists in their turn accused legal dogmatics of using implicit assumptions that are not empirically tested, or when tested turn out to be wrong (for example, in the drafting of new legislation). Rational development of the law requires an economic analysis of the expected effects, they reply, and legal dogmatics cannot provide this. This debate is still undecided, and what's more, it has not made any progress. All the arguments have their legitimacy, given the network of convictions and the background of assumptions in which they find their home. Where there is no common ground, consensus is not even in sight. We are dealing with competing paradigms here; the opposing positions do not only involve diverging pictures of legal scholarship, private law itself, and its connection to legal practice, but they rest on irreconcilable philosophical foundations. ${ }^{15}$ However, this situation need not prevent us from starting our own quest, trying to find our own way between the Scylla of legal dogmatics and the Charybdis of functionalism. This means that we have to disentangle the controversy layer by layer, starting with a closer look at the concept of private law.

14 Richard Posner, 'The decline of law as autonomous discipline: 1962-1987' (1987) 100 Harvard Law Review 761. See: www.academia.edu/29637818/_THE _DECLINE_OF_LAW_AS_AN_AUTONOMOUS_DISCIPLINE_RICHARD_A. POSNER, accessed 23 March $20 \overline{2} 1$.

15 The concept of a paradigm is developed by Thomas S. Kuhn, The Structure of Scientific Revolutions (Chicago: The University of Chicago Press, 1962). It is meant to demonstrate that the growth of knowledge and scientific development are most of the time not smooth processes, but rather the disruptive shift of one paradigm to another (compare the physics of Newton and the New Physics of Einstein and Bohr in the last century); www.researchgate.net/publication/305296586_The_structure_of_scientific _revolutions_Thomas_S_Kuhn_1970_2nd_ed_Chicago_London_University_of _Chicago_Press_Ltd_210_pages, accessed 23 March 2021. 


\subsection{A WRONGFUL LIFE}

A good starting point is the observation that similar societies face similar problems but solve these problems in fundamentally different ways. What unites private lawyers across legal systems, however, is the reasoning they deploy in solving these problems, not the outcomes they reach. ${ }^{16}$ Both observations are illustrated by a hard case that any developed legal system faces, namely the so-called 'wrongful life case'. ${ }^{17}$ Back in 1982, the Supreme Court of California ruled on a case about two sisters - ironically named Hope and Joy - who both suffered from a hereditary hearing defect. ${ }^{18}$ Due to a wrong diagnosis by Hope's doctor, the parents had already conceived Joy before they knew about the seriousness of Hope's disability (she was completely deaf). If they had known the consequences, they would not have wanted another child. The parents claimed (as far as relevant in this appeal case) on behalf of Joy for general damages for being 'deprived of the fundamental right of a child to be born as a whole, functional human being without total deafness' ${ }^{19}$ Is the doctor liable for the allegedly wrongful life of Joy? The answer is twofold. Yes, since if it were not for the negligent conduct of the doctor, Joy would not have been born (assuming that the parents would have had an abortion). But no, it was never within the reach of the doctor to provide a healthy life for Joy, since her deafness was the result of a hereditary defect. So how does the Court find its way out of this dilemma?

The claim suggests that the doctor has forced upon Joy the worst of two alternatives, namely living in a condition like this instead of not having been born at all. The Court first faces the question whether sustaining the claim would imply a devaluation of the value of the 'less-than-perfect' life, and thus

16 Smits (n. 1) vii.

17 A wrongful life claim is a claim to recover damages (under tort law or contract law) because of wrongful conduct of the medical care provider - either directly by causing damage to the unborn child or indirectly by a wrong diagnosis with the consequence that the parents are misinformed - which causes the baby to be born with more or less severe disabilities. These claims are similar to - but to be distinguished from so-called 'wrongful birth cases', in which the claim is based on the birth of an unwanted but healthy child (due to medical failure).

18 Turpin v. Sortini 643 P.2d 954 (CA SC 1982), www.courtlistener.com/opinion/ 1440721/turpin-v-sortini/, accessed 23 March 2021.

19 A wrongful life claim may be filed by the parents (who suffer damages) or the child itself (when it has reached the required age or is represented by the parents), or both. It may be directed against a third party such as the medical care provider, or against the parents (if they have consciously chosen to have the child). The most controversial is the wrongful life claim of a child against its parents based on the proposition that the child would rather not have been born than live in such a condition. 
a violation of the principle of the dignity of human life. Although the Court observes that some courts have rejected wrongful life claims on this ground, it finds it hard to see how an award of damages would disavow the value of life. Neither is it a principle of law that impaired life is always preferable to non-existence. In any case, the choice is to be made by the individual itself or - when a child is involved - by the parents who decide on its behalf. In this particular case, the parents did not have that choice since they were not informed of Joy's condition in time. The negligence of the doctor has robbed them of the option of an abortion. As far as Joy's claim was concerned, the Court bumped into another obstacle. Since the determination of the damages requires a comparison of the present condition of Joy with her non-existence an 'unknowable status', according to the Court - there seems to be no rational or reasonable fashion to determine her damages. So her claim for recovery of general damages was eventually denied. ${ }^{20}$

In many other wrongful life cases, similar arguments have been made to sustain similar outcomes. In common law systems these claims have been refused, ${ }^{21}$ with the exception of Israel. ${ }^{22}$ In civil law systems the outcomes have been similar, ${ }^{23}$ with the exception of the Netherlands. ${ }^{24}$ Some courts have followed the Supreme Court of California in its decision that the assessment of damages is logically impossible, ${ }^{25}$ while others have found difficulties in establishing the required causal connection between the negligence and the disabilities of the child (since these handicaps were - at least partly - due to a hereditary defect). ${ }^{26}$ The case law in South Africa presents a mixed picture. In a ruling of the highest civil court it was considered that these claims confront the courts with the essential question whether the particular child should have been born at all. 'That is a question', the Court then ruled, 'that goes so

20 However, the Court concludes that she may recover special damages for the extraordinary expenses necessary to treat the hereditary ailment. For the US see also Gleitman v. Cosgrove 49 NJ 22 (1967); Park v. Chessin 400 N.Y.S. 2d 110 (1977); Harbeson v. Parke Davis Inc. 98 Wash 2d 460 (1983); and Procanik v. Cillo 97 NJ 339 (1984).

21 In England the leading case is McKay v. Essex Area Health Authority [1982] QB 1166 (CA), on an analysis of common law and the Congenital Disabilities (Civil Liability) Act 1976 (UK), but wrongful life claims have also been refuted in Canada, Australia and Singapore.

22 Zeitsov v. Katz 40 (2) PD 85 (Israel 1986).

23 For Germany BGH 18 January 1983, Entsch. 86, 240; and for France the case of Nicolas Perruche Cour de Cassation 26 March 1996, D. 1997 Jur. P. 35, and Cour de Cassation 17 November 1997, Jur. P. 332.

24 Baby Kelly Hoge Raad 18 March 2005, ECLI:NL:HR:2005:AR5213.

25 See the Belgian Hof van Cassatie 14 November 2014, AR C.13.0441.N.

26 Compare the case of Nicolas Perruche mentioned above (n. 23). 
deeply in the heart of what it is to be human that it should not even asked of the law. ${ }^{27}$ However, in 2014 the Constitutional Court granted leave to appeal in a similar case on the ground that the rights of the child under the Constitution had not been taken into account. ${ }^{28}$ Although the Court recognized the logical difficulties with which wrongful life claims confront us, it pointed out that this framing should not distract us from the underlying value choice. No area of life and law escapes the constitutional values that shape society and no court can escape the dilemmas they impose on us in hard cases. So the decision on the wrongfulness of a disabled life is a legal decision - for courts, to be made in the face of conflicting values - not a decision beyond the boundaries of law (as was ruled by the civil court).

The Constitutional Court continued with the use of comparative law as a tool for assistance. ${ }^{29}$ Attached to its ruling, the Court produced a table containing a comparative overview of the case law of all legal systems that have dealt with wrongful life claims. It concluded that the weight given to different arguments is determined by the constitutional, political and social context, summarized in what we may call 'the legal culture' of the system. Contextual factors that stand out in whether a claim for wrongful life is recognized include the system's stance on abortion, the relative emphasis (or lack thereof) on the rights of children in the judgments on the issue and the type of legal system in place. After reviewing the legal grounds under South African law, the Court addressed arguments that clearly transcend legal doctrine but have actually been used in opposing these claims. First, there is the (pragmatic) argument that sustaining a wrongful life claim may open the floodgates for children to sue their parents. This argument is rejected by the Court, since the child would have to show that it was wrongful or negligent for the parents not to have an abortion while being aware of the disability during pregnancy (which is not easy to establish). Next, there is the argument that recognition of the claim would somehow infringe the dignity of human life because it would imply that a life with a disability is worth less than a life without one. Again, the argument is rejected by the Court, since this is not necessarily the case. Allowing the claim might simply help the child in coping with the disabled life she has to live, as is the case in other cases of physical injury. In addressing these

\footnotetext{
27 Stewart v. Botha 340/2007 ZASCA 84 (2008).

${ }_{28} H$ v. Fetal Assessment Centre ZACC 34 (2014), www.saflii.org/za/cases/ZACC/ 2014/34.htm, accessed 23 March 2021.

29 A. Lollini, 'The South-African Constitutional Court experience: reasoning patterns based on foreign law' (2012) 8(2) Utrecht Law Review 55; I. Giessen, 'The use and influence of comparative law in "wrongful life" cases' (2012) 8(2) Utrecht Law Review 35.
} 
non-doctrinal arguments, this Court is not unique. Other courts have reflected on this broader social and moral context as well. ${ }^{30}$

\subsection{A MODEL OF PRIVATE LAW}

The discourse on wrongful life is in many ways illustrative of the nature of private law. First, it illustrates that private law is not restricted to the boundaries of national jurisdictions. Although its main sources provide valid law within such limits, its arguments and reasoning are in fact transnational (or global, if you like). The same arguments supporting and opposing wrongful life claims have been addressed by courts all over the world. Of course, they have different weight in different legal cultures and may sustain different outcomes - in that sense, and to that extent, they are contextual - but that doesn't mean that they do not contribute to a transnational discourse, as is illustrated by the comparative table that the South African Constitutional Court attached to its ruling. ${ }^{31}$

Next, the discourse on wrongful life sheds light on the limits of private law in an other-than-geographical sense. If we explore the arguments used we may distinguish three categories. The most obvious one is of course the category of the doctrinal arguments. The courts develop their reasoning by interpreting concepts such as wrongfulness, causation and damages. By doing so, they stay within the limits of what is usually regarded as valid law. The discourse on wrongful life is not restricted to these doctrinal arguments, however, but transcends them in at least two ways. First, the courts appealed to the consequences of possible outcomes. Will sustaining the claim open the floodgates to similar claims? Will it result in 'defensive medicine', in the sense that liability will have a 'chilling effect' on the medical care providers? The answers to these questions constitute pragmatic arguments. Although these arguments are not grounds of the decision - like doctrinal arguments - they are in fact part and parcel of the legal discourse. Next, there are the idealistic arguments that express the values at stake. Will sustaining the claim somehow infringe the dignity of the plaintiff? Is the principle of self-determination violated by the failure to inform the parents properly, with the result that they have been robbed of the choice whether or not to have the child? As the Constitutional Court made perfectly clear, at the end of the day the decision rests on the bal-

30 For example, Turpin v. Sortini (n. 18) and Baby Kelly (n. 24) in the rulings mentioned above.

31 See Mitchel de S.-O.-1'E. Lasser, Judicial Deliberations, A Comparative Analysis of Judicial Transparency and Legitimacy (Oxford: Oxford University Press, 2004); and Stephen Breyer, The Court and the World, American Law and the New Global Realities (New York: Alfred A. Knopf, 2015). 
ancing of competing values. All in all, the courts have used doctrinal, principle and pragmatic arguments.

These three types of argument demonstrate three distinctive dimensions of private law, which I call the doctrinal, the idealistic and the pragmatic dimensions. Let me first characterize these dimensions separately, before putting them together in a model of private law.

A. The doctrinal dimension of private law is represented by the rules and precedents that constitute its system. This is what lawyers call 'positive private law', by which they mean the private law that is valid at a certain time in a certain place. Positive private law regulates the mutual rights and duties between private parties, as we have seen, and it provides for the normative framework for social and economic relations. However, people do not always live up to the norms of substantive private law. If they fail to adhere to them, there are other norms of (procedural) law, which inform us as to what might happen next. Substantive and procedural private law are sufficient in most cases.

B. The idealistic dimension of private law is represented by the principles and values that form its normative basis (both morally and politically). If the rules and precedents do not determine the outcome of a case, or the system shows gaps, courts have to find their way out by interpretation and gap-filling. In this process principles and values are helpful, as the constitutional principles in the hands of the South African Constitutional Court have illustrated. At the end of the day, they are embedded in the ideals of social justice that inform positive private law. This explains why we might be confronted with tensions between 'law as it is' and 'law as it ought to be' ('de lege lata' and 'de lege ferenda'). These tensions typically take the form of the dilemma: should we follow the law or should we violate it, in the name of some higher ideal? So the normative principles and values not only inform the choices to be made, they provide the standards for their assessment as well.

C. The pragmatic dimension of private law is represented by the societal practices and usages that form its behavioural basis (both individually and socially). Private law is not only a system of rules and principles, it is also a practice of interests and power. The creation of private law may be the outcome of a political struggle and its enforcement may be the result of execution with the help of the police. This explains why we might be confronted with tensions between 'law as it is prescribed' and 'law as it turns out to be' ('law in the books' and 'law in action'). Sometimes this is the consequence of the legislator and the courts walking two paces behind societal change (for example, in case of technological developments), but sometimes there may be good reasons for a diverging practice (for 
example, trade usages). Sometimes a practice might even flourish as a consequence of the gap between law and practice (compare the success of mediation with judicial adjudication). So behavioural practices and usages not only trigger legal change, they may also function and flourish 'in the shadow of the law'.

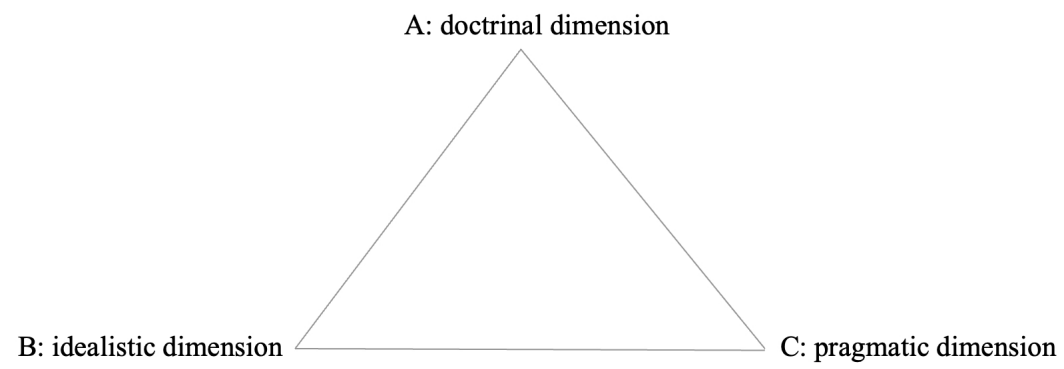

Figure 1.1 The triangle model of private law

This triangle model (Figure 1.1) has little or no theoretical pretensions about what private law is or how it is to be understood, but it does represent a heuristic instrument that may be helpful in understanding how private law functions in its context. Most textbooks present private law only in its doctrinal dimension, as a system of rules and precedents, in order to proceed with contract law, tort law, family law, and other fields of private law. However useful that may be, there are many reasons why we might prefer a richer picture of private law in context, as is presented here. Of these reasons I mention only three here, to give an impression why this approach is not only more challenging but also more realistic. ${ }^{32}$

First, it represents the playing field for private lawyers in their search for the applicable norm to decide a case. Of course, they start their search with the rules and precedents that constitute the doctrinal dimension, but these have what has been called an 'open texture':

Whatever device, precedent or legislation, is chosen for the communication of standards of behavior, these, however smoothly they work over the great mass of

32 Both this model and its pedagogic use find a historical equivalent in the distinction of Julius Stone between 'law as logic', 'law as justice' and 'law as social control' (Julius Stone, The Province and Function of Law: Law as Logic, Justice and Social Control; A Study in Jurisprudence (London: Stevens \& Sons, 1947) 3-43. 
ordinary cases will, at some point, where their application is in question, prove indeterminate: they have what has been termed an open texture. ${ }^{33}$

Suppose you see a sign that reads 'no vehicles in the park'. Of course that implies that it is forbidden to ride in the park with your motorcar or your bicycle, but what about your roller-skates, or a stroller? Rules leave room for doubt on their application, however well specified they are. ${ }^{34}$ Of course, this is a rather simple case, but what about the wrongful life cases we have discussed? In those cases, there was not just one rule to be interpreted. The applicable norm had to be constructed from scratch, tailor-made for the case, so to speak. In such hard cases the private lawyer might turn to the idealistic or the pragmatic dimension to find the ground beneath her feet (as in fact the courts did). What principles does the relevant part of the law express, or what policies does it serve? How are these best realized in the present case? What interpretation or addition of the legal system fits best and offers the best justification of its continuation? ${ }^{35}$ Legal doctrine is embedded in a nest of normative principles and convictions against a background of practices. This is demonstrated by our model of private law, which represents the lawyer's playing field in her search for the applicable norm. We shall come back to this subject (see Chapters 4 and 6).

This is also helpful in avoiding some traditional pitfalls of legal reasoning, which is the second purpose our model serves. When a private lawyer restricts herself to the doctrinal dimension this may easily (but not necessarily) degenerate in to undue formalism. The legal formalist is a caricature of the profession that has haunted its practitioners as long as there has been a developed legal practice ('The first thing we do, let's kill all the lawyers', Shakespeare wrote $^{36}$ ). There is a reason why this picture is so persistent: the temptation of formalism is never far away. For private lawyers, it is tempting to become formalists, since it justifies their exclusive domain of expertise and professionalism. Formalism is a temptation to be resisted, however, when it means that private lawyers leave their sense of justice and context at home when they go to work. Of course, this does not imply that their private sense of justice must be foremost in their daily work. Such moralism may be as tempting as formalism, but it is as objectionable. The moralist is just another caricature of

H.L.A. Hart, The Concept of Law (Oxford: Oxford University Press, 1961) 124.

We shall address this in Chapter 3.

35 Ronald Dworkin, Law's Empire (Cambridge, Mass.: The Belknap Press of Harvard University, 1986) 176-276.

36 William Shakespeare, Henry VI, Part 2, Act IV, Scene 2. 
the profession that time and again pops up in legal discourse (for example in 'le bon juge Magnaud'). ${ }^{37}$

Magnaud was the president of the tribunal of first instance at Château-Thierry between 1899 and 1914, in which capacity he acquired the nickname 'le bon juge' ('the good judge'). He deserved that name for consistently deciding in favour of the weaker party, in terms of poverty and social status. He not only acquitted a woman who justified her theft of bread by a plea of hunger, but also allowed for damages without fault, extended the principle of responsibility without fault to cases in which passengers of railroads sued the carrier, and allowed good faith to be pleaded when damages were sought for statutory trespasses, such as hunting on another's land. Sometimes his rulings were within the scope of his discretion - both in assessing the facts and in interpreting the law - and sometimes they were in clear violation of established case law and doctrine. In any case they were justified by principles clearly stemming from his conscience (not from the law), such as: 'Uprightness and delicacy are virtues infinitely easier to practise when one lacks nothing than when one is absolutely destitute.' Magnaud scorned droit juridique (legal law), and would be guided only by equity, which - in his hands - turned out to be a policy of liberal and social reform. Indeed, Magnaud left the bench after 15 years to enter Parliament. When looking back at his years on the bench he expressed his judicial philosophy as follows: 'The judges of the tribunal of Château-Thierry derived their decisions from their conscience alone and rendered judgments that seemed equitable to them, because they always kept in mind that the legislature could have intended only an equitable result, and that if the text of a statute seemed apparently to lead to inequity, it is incontestable that this inequity was not intended by the legislature. ${ }^{38}$

Magnaud had practically no followers on the bench. Judging is not promoting one's own moral convictions at the expense of the public interest. Neither is it about the pursuit of one's own political beliefs and ideals. If we take the pragmatic dimension of private law to be the starting-point, that would alter our profession to a kind of activism (the lawyer as 'social engineer'). ${ }^{39}$ Again, Judge Magnaud provides a perfect illustration since his conscientious decisions were in fact informed by his social and political programme. Formalism, moralism and activism represent the main pitfalls of legal reasoning and legal professionalism, however, since they each de-contextualize one of the dimensions of private law (the doctrinal, idealistic and pragmatic dimension respectively). These 'isms' are to be avoided since they each reduce private

37 H. Leyret, Les Jugements du président Magnaud (Paris: P.V Stock éditeur 1900); and Les Nouveaux jugements du président Magnaud (Paris: Schleicher frères \& Cie éditeurs 1903).

38 Max Radin, 'The good judge of Château-Thierry and his American counterpart' (1922) 10(4) California Law Review 300-310, www.jstor.org/stable/3474535, accessed 23 March 2021.

39 Posner, 'The decline of law as autonomous discipline: 1962-1987' (n. 14) 761-780; Posner, Overcoming Law (n. 12) 33-171. 
law to one of its dimensions. Our model illustrates that judging or lawyering in fact resembles three cushions in the game of billiards, since it involves not just one but all three edges of the field.

If we take a step back, we can see a third function the model serves: it may be helpful in understanding the dynamics of a legal system. Take, for example, the wrongful life cases, which came about as a consequence of new medical technology for prenatal diagnostics (C: the pragmatic dimension). As a result, parents nowadays may be confronted with new dilemmas of a moral and even existential nature: our child, as yet unborn, suffers from defects of a specific nature. Do we still want to have the baby? Or are its disabilities a cause to consider the option of an abortion? What would our child itself want, once it is born and has reached the age of maturity? New dilemmas also arise for medical care-providers and disabled children. Birth and death are no longer given by nature, to be accepted as our fate, but have become the result of human action and choice. In the face of these new dilemmas our moral values are reconsidered and sometimes even reinterpreted (B: the idealistic dimension). This has brought these life events within the reach of private law as well: what (written or unwritten) norms govern our actions vis-à-vis life and death? When do they - if violated - constitute liability for the wrongdoer? In other words, what are the implications of the sketched developments for doctrinal private law (A: the doctrinal dimension)? Since more and more courts have dealt with wrongful life cases, we now have established case law. This development in many legal systems (A: doctrinal dimension) has in its turn influenced convictions and principles (B: idealistic dimension), as well as established practices (C: pragmatic dimension). This dynamic between the different dimensions of private law is well illustrated by the triangle model of private law. If we want to understand why, however, we have to dig somewhat deeper in legal philosophy.

\subsection{GRAND OLD THEORIES OF LAW}

The concept of private law is connected to that of law in general, of course. Although the question of the concept of law is prima facie a theoretical issue, we shall see that on closer inspection it has practical consequences as well. The reason why we think it is worthwhile to make this sidestep is that the three Grand Old Theories on the concept of law each take one of the dimensions of (private) law that we have distinguished as defining for its nature. In that sense they each focus on one dimension, while neglecting or at least underestimating the others. When speaking of the three Grand Old Theories of law, I refer to legal positivism, natural law theory, and legal realism, respectively. Legal positivism takes the doctrinal dimension as defining for the nature of law (A in the triangle model). The concept of law refers to positive law, the law that is valid at a certain time and place. Legal positivists do not deny the existence 
and relevance of principles and values as well as practices and usages, but they hold that these are not part of law, properly understood (with the exception of some overlap). Principles and values belong to the domain of morals and politics, which is conceptually distinct from that of law. Surely, there may be overlap (for example enacted legal principles), but there is no conceptual connection. On the other hand, practices and usages belong to the empirical domain of facts, to be distinguished from the normative domain of the law. Again, there may be overlap (for example customary law), but in principle they are separated. Legally enacted rules and decisions are what constitutes law, nothing more or less.

This central claim of legal positivism is challenged by both natural law theory and legal realism, albeit from different angles. Natural law theorists take the idealistic dimension as defining for the nature of law ( $\mathrm{B}$ in the triangle model). According to them, positive law is conceptually connected to principles and values, with the consequence that positive law by definition has a moral quality. Legal realists, on the other hand, take the pragmatic dimension as defining for the nature of law ( $\mathrm{C}$ in the triangle model), with the consequence that what constitutes law is in the end what people do when they follow or apply the law. So each of the Grand Old Theories of law holds one of its dimensions to be defining. Our triangle model, however, tries to capture the idea that they are all relevant, exemplifying different dimensions of private law. Of course, this does not imply that the theorists all got it wrong. First, the triangle model does not pretend to define the concept of law. It rather tries to demarcate the playing field of private-law-in-context for educational purposes. Moreover, taking the Grand Old Theories together, they sketch a picture of law similar to the triangle-model. To understand better what is at stake here, we have to understand better what each theory entails in more detail, and then research the relevance of the controversy.

Prima facie, legal positivism has the advantage of the obvious. The idea that the concept of law refers to the law that is valid at a certain time within a jurisdiction seems evident. The follow-up question as to what constitutes validity is then answered with a reference to the prevailing conditions within that jurisdiction. According to the German legal positivist Hans Kelsen (1881-1973) a rule is valid when enacted by an authorized legislator. This legislator is authorized by a higher legislator, which in its turn derives its authority from an even higher legislator. Finally, we reach the constitution of that jurisdiction, the source of all legislative authority within the system. The question into the source of authority is repetitive, however. One might question the authority of the legislator of the constitution, which refers to the previous constitution, and 
so on. What emerges from this analysis is a picture that Kelsen has called the Stufenbau (stepped construction) of the legal system (Figure 1.2). ${ }^{40}$

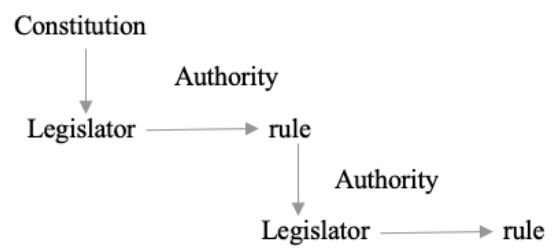

Figure 1.2 The Stufenbau of a legal system

Although this picture is intuitively attractive, it faces serious difficulties. The question into the source of authority is still unanswered when we have reached the first constitution; from which source does the legislator of the first constitution derive its authority? Kelsen postulated what he called a Grundnorm, a hypothetical norm explaining the validity of the system as a whole. Since this Archimedean point of the legal system is presumed to exist - but does not exist in fact - it seems to constitute a major flaw in the picture presented. ${ }^{41}$

At this point, we switch to the modern version of legal positivism presented by the British legal philosopher H.L.A. Hart (1907-1992). In his book The Concept of Law (1961) he sketches a picture of a modern legal system as a union of primary rules and secondary rules. ${ }^{42}$ Primary rules are the rules directed at individuals, regulating their behaviour by imposing duties upon them. Secondary rules are not concerned with the actions of individuals, but with the primary rules themselves. They confer powers upon individuals or institutions - public or private - such as the power to introduce new rules or extinguish or modify old ones (rules of change), to make authoritative determinations of whether primary rules have been broken (rules of adjudication), or rules for the conclusive identification of primary rules (rules of recognition). When we say that a certain rule is a valid rule of law, we mean that it satisfies the criteria provided by a rule of recognition. The validity of the system as a whole is based on an 'ultimate rule of recognition', which provides the criteria for the identification of the system as they are exemplified in the official

\footnotetext{
40 Hans Kelsen, Reine Rechtslehre (Vienna: Österreichische Staatsdruckerei 1960) 228-283.

41 Kelsen (n. 40) 196-228.

42 Hart (n. 33) 77-97.
} 
behaviour of its officials. The existence of the system as a whole is grounded on a social rule, a complex practice of the courts, officials and private persons, identifying the law by reference to certain criteria. As such, it is based on a social practice of those living in it and upholding it (the "ultimate rule of recognition'), and not on a hypothetical notion presumed to explain its existence (the Grundnorm). In this respect Kelsen and Hart diverge, albeit they both defend legal positivism.

What distinguishes natural law theory from legal positivism is that the validity of law is not (primarily) dependent on its formal structure and characteristics, but on its substantive content. Adherents of natural law theory - from whatever origin or time - focus on the values and principles that constitute the content of law. An eminent representative is the German legal philosopher Gustav Radbruch (1878-1949), who was a legal positivist before the Second World War but switched to natural law after the war (the so-called Umbruch of Radbruch). During his whole life Radbruch had professed that the concept of law is a cultural notion, which means that it is directed at the realization of values. The concept of law is, more particularly, directed at the idea of law (Rechtsidee), which is justice in the sense of equality (same cases alike, different cases different in accordance with their difference). This, however, does not inform us as to the perspective under which equality is to be judged, nor on the consequences of this judgement. For this we need two other elements of the idea of law, namely efficacy and legal certainty. In Radbruch's terminology, these three elements of the idea of law - justice, efficacy, and legal certainty - are referred to as the 'antinomies' of the idea of law (compare the idealistic, pragmatic and the doctrinal dimensions of the triangle model). As a lawyer, Radbruch knew that these antinomies cannot always be realized at the same time; one often has to strike a balance between them. ${ }^{43}$ Near the end of his life he reached the conclusion that the tension between law and justice can become so unbearable that justice prevails over positive law and the latter is not law any more (properly understood). As soldiers had been ordered that 'Befehl ist Befehl', so the lawyers had been taught that 'Recht ist Recht'. This had made them defenceless in the face of gross injustice. A dehumanizing treatment of groups of people (as Untermenschen) is a clear violation of the principle of equality that defies the qualification of law. Alternatively, the respect for human rights and basic principles is a constitutive and thus defining element of law, whatever its formal characteristics. ${ }^{44}$

43 Gustav Radbruch, 'Antonym der Rechtsidee', in Erik Wolf and Hans-Peter Schneider (eds), Rechtsphilosophie (Stuttgart: K.F. Koehler Verlag, 1973) 164-169.

44 Gustav Radbruch, 'Fünf Minuten Rechtsphilosophie' (1945), in Erik Wolf and Hans-Peter Schneider (eds), Rechtsphilosophie (Stuttgart: K.F. Koehler Verlag, 1973) 327-329; Gustav Radbruch, 'Gesetzliches Recht und übergesetzliches Unrecht' (1946), 
The reproach that legal positivism had made the German lawyers defenceless in the face of Nazi law is opposed by Hart. He argues that the question whether positive law is just or not is not a legal, but a moral question. The duty to obey the law is not to be confused with the validity of law. According to Hart, Nazi laws were valid, even if they violated basic principles. German lawyers had to decide whether to obey the law on moral grounds, however, and not on legal grounds. If legal positivism has taught them that they should not always obey valid positive law, then it has made them resilient, not defenceless. ${ }^{45}$ Apart from the psychological question of which theory makes lawyers most resilient in the face of unjust laws, the theoretical issue is whether the validity of law constitutes an obligation to obey the law (or not). In a natural law theory the answer is affirmative, whilst in a legal positivist theory it is not. The reason is that in a natural law theory, positive law answers to a 'higher law' (natural law) if it is to be valid and thus has to be obeyed. The dilemma whether to obey positive law that is clearly unjust is as old as mankind. Long ago, in the Greek tragedy Antigone by Sophocles (written in $440 \mathrm{BC}$ ), the dilemma emerges when King Kreon forbids the burial of the dead. In clear violation of this order, Antigone buries her brother Polyneikes. As a defence she appeals to the unwritten laws of divine origin with universal validity; it is in no man's hands - not even those of King Kreon - to violate these eternal laws. History has learned that every time a ruler enacts laws that contain gross injustice, disobedience is justified by an appeal to a 'higher' law; not only by Radbruch or Antigone, for that matter, but also by Socrates and Martin Luther King (to mention just two).

In 399 BC Socrates was - at the age of 70 - convicted for blasphemy and corrupting the young with subversive thoughts. After refusing to go in a voluntary exile he had to confront a jury of 500 men. He was convicted (by a small majority) and condemned to death by poison. In his Apology he boasted that he never obeyed unjust orders. When he was ordered by the oligarchic regime to arrest Leon the Salaminian and to bring him before the rulers, for example, he refused and just went home: 'Then, however, I showed again, not in speech but in deed, that I do not even care about death in any way at all - if it is not too crude to say so-but that my whole care is to commit no unjust or impious deed. ${ }^{46}$ When Socrates was subsequently imprisoned, his friend Crito offered him the opportunity to escape. Socrates reasons, however, against his own interests, that he is obliged to obey the

in Erik Wolf and Hans-Peter Schneider (eds), Rechtsphilosophie (Stuttgart: K.F. Koehler Verlag, 1973) 339-351.

45 H.L.A. Hart, 'Positivism and the separation of law and morals' (1958), in H.L.A. Hart, Essays in Jurisprudence and Philosophy (Oxford: Clarendon Press, 1983) 49-88.

46 T.G. West (ed.), Plato's Apology of Socrates (Ithaca, NY: Cornell University Press) para. 33c-e, www.sjsu.edu/people/james.lindahl/courses/Phil70A/s3/apology .pdf, accessed 23 March 2021. 
laws of the state (his own unjust conviction included), since he consented to those laws, profited from them, and is therefore under the obligation to comply. Either he has to convince the authorities that he is right, or he has to obey them until the end. ${ }^{47}$ In comparison with the Apology, this is a paradoxical point of view: are we now to obey unjust laws, or not?

Less paradoxical is Martin Luther King in his Letter from Birmingham City Jail. ${ }^{48}$ He wrote this public letter when imprisoned, after being convicted for non-violent participation in a demonstration against segregation. I am in Birmingham since here is injustice, so he writes, and 'injustice anywhere is a threat to justice everywhere'. Of course, it was illegal to participate in the demonstration, but it was nevertheless justified, since these laws were unjust. What makes a law unjust then? King writes:

A just law is a man-made code that squares with the moral law, or the law of God. An unjust law is a code that is out of harmony with the moral law. To put it in the terms of St. Thomas Aquinas, an unjust law is a human law that is not rooted in eternal and natural law.

How does this affect laws institutionalizing segregation? King's answer is in line with the foregoing:

An unjust law is a code that a majority inflicts on a minority that is not binding on itself. This is difference made legal. On the other hand, a just law is a code that a majority compels a minority to follow, and that it is willing to follow itself. This is sameness made legal.

An unjust law is a law that makes difference legal, resulting in injustice, a clear violation of natural law.

The debate between legal positivism and legal realism is of a different nature. What distinguishes legal realism from legal positivism and natural law theory is that the validity of law is considered to be not (primarily) dependent on its formal structure and characteristics, nor on its substantive moral content, but on actual efficacy in practice. A rule of law is only valid if it actually influences human behaviour, whether of the authorities (American legal realism) or of the justice seekers (Scandinavian legal realism). As a consequence of their epistemological outlook, realists only acknowledge sensory perceptible facts; the rest is a matter of belief. This means that they do not only deny the existence of a higher (natural) law, but also that of a normative reality of a formal nature, and thus they reject both natural law theory and (formal) legal positivism as fairy tales (believing in non-existent entities). One of the prominent representatives of legal realism was the American scholar and judge, Oliver Wendell Holmes (1841-1935). He resisted the then prevailing formal approach of the law by claiming that law should not be studied as an ideal system, but as an

47 C. Woods and R. Pack (trans.), Crito (San Francisco, Calif.: Creative Commons 2007) paras 51c-52d, www.pitt.edu/ mthompso/readings/crito.pdf, accessed 23 March 2021.

48 www.csuchico.edu/iege/_assets/documents/susi-letter-from-birmingham-jail .pdf, accessed 23 March 2021. 
imperfect practice. Law can best be understood from the perspective of the 'bad man', always aware of the consequences of his actions. What law is, is eventually determined by the courts: 'The prophecies of what the courts will do in fact, and nothing more pretentious, are what I mean by the law.' ${ }^{49}$ Of course, this statement is more in place in a common law system than in a civil law system, where enacted legislation plays a more prominent role as a source of law. Nevertheless, it expresses a demythologizing thought with respect to law and legal discourse that is relevant in both common and civil law systems.

\subsection{THREE INTERMEDIATE POSITIONS}

The core idea of the triangle model presented in Section 1.4 is that the doctrinal, idealistic and pragmatic dimension of private law can be distinguished but cannot be separated. Moreover, neither of these dimensions enjoys exclusivity, since only in combination do they sketch a comprehensive picture of private law. As the wrongful life cases have illustrated, arguments of all three kinds are used and recognized as authoritative in legal discourse. None of the Grand Old Theories of law can account for that. However, since the Second World War, legal philosophers have worked hard to develop in-between positions that avoid their flaws while combining their merits. Some of their ideas deserve our attention, since they illustrate the nature of private law by underlining the connections between its different dimensions.

As a start, it is worthwhile to remember how Radbruch in his later work sought a middle ground between legal positivism and natural law theory. Law is a human project, according to Radbruch, which entails that it neither belongs to nature (like natural law theory claims), nor that it is always the product of design (like legal positivism implies). The concept of law is a cultural concept, directed at the realization of the idea of law (Rechtsidee). Law might be unjust - 'summum ius, summa iniuria' - but it is only law since its purpose is justice. This picture of law as a cultural heritage - 'die Arbeit der Jahrhunderte' explains why law is intrinsically connected to values and principles. Radbruch calls it 'cultural law' or 'natural law with diverging content', which underlines the mode of existence of (private) law in his in-between position. As a consequence then, legal scholarship is a cultural discipline (one of the humanities, or Geisteswissenschaften).

Following up on this idea of law as culture, the American legal philosopher, Lon Fuller (1902-1978), developed a theory often referred to as interac-

49 Oliver Wendell Holmes Jr, 'The Path of the Law' (1897) 10 Harvard Law Review 457, reprinted in his Collected Legal Papers (New York: Harcourt, Brace \& Company, 1920) 167, 173, http://moglen.law.columbia.edu/LCS/palaw.pdf. 
tionism. In his book The Morality of Law (1964), Fuller develops a forceful response to the 'command theory of law' that pictures law as an order backed by threats. ${ }^{50}$ Sometimes legal rules indeed guide individual behaviour by providing reasons for action (for example, a red traffic light providing a reason to stop). In other cases, however, legal rules establish a relation between individuals in which mutual expectations provide reasons for action (for example, the rules of contract law). In these cases the legitimate expectations of individuals constitute (unwritten) norms that guide people's behaviour (rather than the enacted rules). The emergence of unwritten norms in human interaction is especially important in the open system of private law with a prominent position for concepts such as acting in 'good faith', or acting in compliance with the behaviour of 'the average man'. In those instances the rules of contract law and tort law provide the normative framework within which unwritten norms are constituted by human interaction. Our triangle model illustrates this. All the rules and precedents of private law leave undetermined what is in accordance with the demands of good faith in a specific case. In that sense, they have open texture, as we saw in Section 1.4. As a consequence, the norm that is constituted in the specific case is not just the result of the rules and precedents (A: the doctrinal dimension), but also of the values and principles that guide their interpretation (B: the idealistic dimension), as well as the practice in which they find their home (C: the pragmatic dimension). Legal norms are thus embedded in human interaction.

Another in-between argument that we owe to Fuller is the notion of 'procedural natural law'. Fuller argues that law has an 'internal morality', that is, it has to comply with its own basic values. Suppose a fictional king, Rex, constantly enacts arbitrary legislation or makes arbitrary decisions. Even if they are not morally wrong ('external morality'), there are serious flaws with regard to their legality ('internal morality'). Would we just say he makes bad law, or should we say that what he makes is not even law at all (properly understood)? Rules have to be in compliance with certain requirements of legality, that is (1) they should be of a general character, (2) properly enacted, (3) without retroactive force, (4) phrased in clear language, (5) not inconsistent, (6) not so demanding that people cannot act in accordance with them, (7) not constantly changing, and (8) used as a ground for authoritative decision-making. Similarly, judicial decisions have to be in accordance with the demands of a fair trial (compare Article 6 ECHR). Together these requirements of legality constitute an internal morality of law that is a kind of 'procedural natural law'.

50 Lon L. Fuller, The Morality of Law (New Haven, Conn.: Yale University Press, 1964). For the command theory of law, see John Austin, The Province of Jurisprudence Determined (London: John Murray, 1832). 
Fuller's viewpoint is not completely procedural, however, since he suggests that there is a substantive element involved as well, namely the importance of communication through law:

If I were asked, then, to discern one central indisputable principle of what may be called substantive natural law - Natural Law with capital letters - I would find it in the injunction: Open up, maintain, and preserve the integrity of the channels of communication by which men convey to one another what they perceive, feel, and desire. $^{51}$

Communication is of primary importance. The human capacity to communicate has made it possible to survive and transfer our cultural heritage to the next generations. Communication is more than a way of staying alive, Fuller argues, it is also a way of being alive. The way and extent in which we succeed in communicating successfully expands or contracts the boundaries of our life. As Wittgenstein wrote: 'The limits of my language mean the limits of my world. ${ }^{52}$ This applies to law as well, as it is intrinsically connected with language (Chapter 3). Law is an important means of communication in a political community, constantly shaped by the communication of its members.

The third important post-War contribution to be mentioned here is the writings of the American legal philosopher, Ronald Dworkin (1931-2013). Dworkin started with a forceful critique of the legal positivism of Hart, which he called 'a model of rules'. Legal positivists totally neglect the crucial role of principles in a legal system, Dworkin argues. ${ }^{53}$ Take Elmer's case. Elmer killed his grandfather by poisoning him in New York in 1882. His grandfather's will would leave him the bulk of the estate, but Elmer had reason to fear that his grandfather would change the will (since he had remarried recently). Elmer's crime was discovered, however, so he was convicted and sentenced to jail. Now the question arose as to whether he was entitled to his grandfather's inheritance, since this was contested by the residuary legatees under the will. The applicable New York statute of wills did not contain provisions on a situation like this. Elmer's lawyers argued that he was entitled to inherit since the will was valid and he was named in the will. Judge Earl, writing for the majority, decided differently. He wrote that statutes are to be interpreted against the background of general principles of law. Since they are part of law as a system, they should be interpreted in a way that makes the law as a whole more coherent. Since the law elsewhere respects the principle that no one should

\footnotetext{
$51 \quad$ Fuller (n. 50) 186.

52 Ludwig Wittgenstein, Tractatus Logico-Philosophicus (London: Routledge \& Kegan Paul, 1922) para. 5.6.

53 Ronald Dworkin, Taking Rights Seriously (London: Duckworth, 1978) 1-81.
} 
profit from his own wrongdoing, so the statute of wills must be interpreted to deny inheritance to someone who has murdered for that purpose.$^{54}$ Clearly, principles play an important role in law and adjudication. For legal positivists this is a major problem, since principles differ essentially from rules. They do not apply in an all-or-nothing fashion but have a dimension of weight. If two rules conflict, one of them cannot be valid. Two principles can, however, be applicable at the same time. Moreover, principles are binding not because they are enacted, but because of their content. Principles have a moral content, as is illustrated by the principle that nobody may profit from his own wrongdoing. Together they form the 'moral cement' of the law.

In Dworkin's view, law is a system with its own coherence or - in his words - integrity, since it is the optimal expression of the values and principles that are constitutive of the political community. ${ }^{55}$ Freedom, equality and solidarity are not just ornaments, they form the framework within which legal rules acquire meaning and within which cases are decided. Against this background, it is the court's responsibility in each individual case to find the best possible interpretation of the law, that is, the interpretation that fits best and that offers the best justification for law. In this context Dworkin defends his 'right answer thesis', which implies that for any case there is one right answer, namely the one that provides the best fit and justification. If this contradicts our intuition - since in hard cases diverging decisions may seem plausible - it is because we may not know the right answer (compare the wrongful life cases we discussed). In those cases it takes a judge with 'superhuman talents and endless time' - a Hercules, in Dworkin's phrasing - to come up with the right answer. ${ }^{56}$ That answer, in its turn, contributes to the continuation of the law. Legal development is comparable with the process of writing a chain novel, so Dworkin argues, since each new chapter has to fit in the story and to contribute to its best possible continuation. As such, law is continued as the best possible expression of the underlying values and principles. In this way the political community shapes its own constitution.

Summarizing the results of our excursion into legal philosophy (Sections 1.5 and 1.6), we have found some interesting elements to give flesh to the bones of the triangle model of private law (Section 1.4). Firstly, the Grand Old Theories of law each take one of the corners of that model as defining, which reduces law to one of its dimensions while neglecting the others. In fact, lawyers seem to use the whole triangle as their playing field, as the wrongful life cases illus-

54 Ronald Dworkin, Law's Empire (Cambridge, Mass.: The Belknap Press of Harvard University Press, 1986) 15-20.

55 Dworkin (n. 54) 176-276.

56 Dworkin, Law's Empire (n. 54) 245. 
trate. Secondly, law is part of human culture (as Radbruch has pointed out), which implies that it is intrinsically connected with the values which it aims to realize (especially justice). This repeatedly creates tensions between the core values of law, namely legal certainty, justice, and efficacy (served by the doctrinal, idealistic and pragmatic dimension respectively). Thirdly, cases are solved by the construction of norms, as the result of the interpretation of rules and precedents, in the light of values and principles, against the background of practices and human interaction. Fuller has pointed out that norms are in fact legitimate expectations arising in interaction (interactionism), communicated in and by the law (with its own internal morality). Finally, principles play a crucial and distinctive role in law, not only in solving hard cases (such as Elmer's case), but also in understanding how law evolves in a political community, constantly adjusting to changing circumstances. Dworkin has shown how law evolves like the writing of a chain novel, with each chapter providing a fit with as well as a justification for the previous ones, thus paving the way for future ones. Law is like a story, told and repeatedly retold, not for its own sake, but for the sake of living together as members of a political community in a decent and principled manner.

\subsection{THE TRANSNATIONAL DIMENSION}

However different they may be, the theories addressed in the last paragraph share one implicit presupposition, namely that the home of private law is the nation state with its own jurisdiction and that our activities fall under one jurisdiction at a time. ${ }^{57}$ In reality, we are not just members of one political community, but we live in a world of multiple overlapping communities. I am a Dutch citizen and thus subject to Dutch (civil) law as well as to the law and regulations of political subdivisions such as towns, provinces, neighbourhood districts, water regions, and so on. When my actions trespass the boundaries of my jurisdiction, they are subject to laws of conflict, or to international private law. Traditionally, international private law encompasses the rules of conflict if citizens of that jurisdiction come into contact with another jurisdiction (by marriage, business, accidents, or whatever cause). The problems to be solved are the question of jurisdiction (who is authorized?), choice of law (which rules apply?), and recognition of judgments (how to execute them?). Since globalization and the use of the internet have extended the legal effects of our actions and transactions far beyond the boundaries of national jurisdictions, these

57 Paul Schiff Berman, Global Legal Pluralism, A Jurisprudence of Law beyond Borders (n. 4) 3-61. 
issues have become more complex to the extent that the notion of a territorial jurisdiction is questioned.

An example is the judgment of a French court in 2000, asserting jurisdiction over a web portal exploited by Yahoo! ${ }^{58}$ The website allowed the posting of Nazi paraphernalia and Third Reich memorabilia, which were uploaded in the United States and downloaded in France. This raised questions on the legality of this practice, which was a criminal offence in France, but was protected by the freedom of speech in the United States. Two French non-profit organizations fighting anti-Semitism filed a civil complaint against Yahoo! US and Yahoo! France. In its judgment of 22 May 2000 the High Court of Paris upheld the claim, ordered Yahoo! US to dissuade and prevent access to auctions for these items, and ordered Yahoo! France to warn users against the risk of illegal purchases. After Yahoo! US and Yahoo! France challenged the competence of the High Court, the Court reasserted its competence and confirmed its previous decision. After this judgment, Yahoo! US filed a complaint against the French non-profit organizations before the US District Court for the Northern District of California in San José, claiming that the French judgment constituted a violation of the First Amendment to the American Constitution and was therefore not enforceable in the US. Although the District Court upheld the claim, this decision was reversed by the Court of Appeals in 2004, which found that the District Court lacks jurisdiction over French non-profit organizations. ${ }^{59}$ This case illustrates the difficulty of a territorial analysis: where do the transactions on the website take place? In France, in the US, both, or neither? And what does this imply for the jurisdiction of French and US courts? And for the applicable norms? Are the courts to claim jurisdiction? And if so, are they to apply the norms of their own jurisdiction? These questions - not unusual in international private law - become more complex in a globalized and digitalized world. ${ }^{60}$

Moreover, as a Dutch citizen I am not only subjected to national law - from whatever origin - but also to transnational institutionalized communities, such as the European Union and the Council of Europe. Both claim to constitute a new legal order - over and above those of the member states - with its own institutions for legislation and adjudication. The European Union, moreover, claims superiority over national law as well as direct effect within national legal systems. ${ }^{61}$ Interaction between the courts of the member states and the European Court of Justice in Luxembourg (the ECJ) is established through a preliminary reference procedure, allowing the national courts to ask preliminary questions on the validity and interpretation of EU law (Art. 267 TFEU).

58 UEJF et Licra c/ Yahoo! Inc. et Yahoo France (2000) Tribunal de Grande Instance (TGI) Paris, www.juriscom.net/txt/jurisfr/cti/tgiparis20000522.htm.

59 Yahoo!, Inc. v. LICRA (2006) Case no. 01-17424 (US Court of Appeals for the Ninth circuit).

60 For more, similar examples, see Schiff Berman (n. 4) 30-31.

${ }_{61}$ Case C-6/64 Costa/ENEL (1964) ECLI:EU:C:1964:66; Case C-26/62 Van Gend en Loos (1964) ECLI:EU:C:1963:1. 
This procedure has turned out to be an effective means of coordination of the two legal systems.

An illustration is offered by the case of Mohammed Aziz, a Moroccan national living in Spain. ${ }^{62}$ In 2007 he concluded, before a notary, a loan agreement secured by a mortgage with the Catalunyacaixa bank. The immovable property subject to the mortgage was Aziz's family home, which he had owned since 2003. The loan agreement obtained very unfavourable conditions, however. If Aziz failed to comply with the agreement he would be under an obligation to pay an annual default interest of 18.75 per cent (without prior notice). In that case, the bank would be entitled to call in the totality of the loan on expiry of a stipulated time limit. Finally, the bank would not only have the right to bring enforcement proceedings to reclaim any debt but also, for the purposes of those proceedings, it could immediately quantify the amount due by submitting an appropriate certificate indicating that amount. When Aziz lost his job and was no longer able to pay the mortgage, he was evicted from his home. Shortly before, however, he had requested a declaratory judgment seeking the annulment of the relevant provisions on the grounds that they were unfair. Under Spanish law, however, this ruling could only lead to compensation in the form of damages, and it could not prevent the eviction. So the court in Barcelona asked preliminary questions to the ECJ to the effect of whether this constituted an infringement of Directive 93/13/EEC of 5 April 1993 (on unfair terms in consumer contracts). The ECJ answered the questions affirmatively, taking into account that 'the mortgaged property is the family home of the consumer whose rights have been infringed, since that means of consumer protection is limited to payment of damages and interest and does not make it possible to prevent the definitive and irreversible loss of that dwelling' (para. 61).

The Council of Europe enacted the European Convention on Human Rights and institutionalized a system in order to effectuate its content in the jurisdiction of its member states. According to Article 1, the primary responsibility for securing the rights and freedoms of the Convention rests on the shoulders of the member states, which implies that the role of the European Court of Human Rights in Strasbourg (the ECHR) is subsidiary. This is mirrored in the margin of appreciation that is left by the ECHR for the member states in the interpretation of the Convention. This, however, has not diminished the impact of the Convention on the legislation and adjudication of the member states, even on questions of private law where it was not to be expected.

An example of the far-reaching impact of the Convention is the Dutch case on climate change liability (the Urgenda case). ${ }^{63}$ In this case, a claim was filed by Urgenda - a foundation serving the general interests of a sustainable world - against the State of the Netherlands. Urgenda sought an injunction to reduce the emission of GHGs (greenhouse gases) by 25 per cent by the end of 2020 (compared to 1990).

62 Case C-415/11 Mohamed Aziz (2013) ECLI:EU:C:2013:164.

63 HR December 20, 2019 ECLI:NL:HR:2019:2006. 
The claim was upheld by the Hoge Raad and it ordered the State of the Netherlands to adjust its emissions policy. The decision was based on Articles 2 and 8 of the Convention (protecting respectively the right to life and the right to a clean environment), as well as a host of scientific evidence that anything less would constitute a danger for the population (those of neighbouring countries and future generations included). Since the applicable Articles 2 and 8 of the Convention are not restricted to Dutch law but apply in the jurisdictions of all member states to the Convention, the international impact of this ruling is significant. ${ }^{64}$

As well as these governmental institutions and jurisdictions, many non-state communities may impose normative force over our behaviour, such as industry standard-setting bodies, non-governmental organizations, religious institutions, ethnic groups, social networks, commercial institutions, and so on.

A notorious illustration is the scandal of the so-called PIP implants. This breast implants, manufactured by French company Poly Implant Prothèse (PIP), were made with industrial silicone which did not comply with the quality standards for different usages. Hundreds of thousands of women all over the world were negatively affected. In the meantime the producer became insolvent. One of the victims was Mrs Schmitt, who sought damages from the safety certifier TÜV Rheinland, a private company that had certified the faulty implants. Since the quality assurance system is regulated by EU law (Directive 93/42/EEC of 14 June 1993 concerning medical devices), the Bundesgerichtshof of Germany asked the ECJ preliminary questions about its interpretation. The ECJ ruled that a notified body such as TÜV Rheinland - although not under a general obligation to conduct unannounced inspections - is, in the face of evidence that a medical device is not in compliance with the Directive, under the obligation to take all steps necessary to ensure that it complies with the Directive. The purpose of its involvement is in any case to protect the end-users of medical devices. The conditions under which that gives rise to liability are governed by national law, subject to EU principles ${ }^{65}$ This may be per-

${ }^{64}$ See for comments J. Lin, 'The first successful climate negligence case: a comment on Urgenda Foundation v. The State of the Netherlands (Ministry of Infrastructure and the Environment)' (2015) 5 Climate Law 65; Robert B. McKinstry Jr, 'Potential implications for the United States of the Urgenda Foundation v. Netherlands decision holding that the UNFCCC and international decisions required developed nations to reduce emissions by $25 \%$ from 1990 levels by 2020 ' (2015), https://ssrn.com/abstract= 2632726, accessed 23 March 2021. Moreover, the Urgenda ruling has triggered similar filings. See E. Stein and A.G. Castermans, 'Case comment - Urgenda v. The State of the Netherlands: the "reflex effect" - climate change, human rights, and the expanding definitions of the duty of care' (2017) 13 McGill Journal of Sustainable Development Law 305-324.

65 Case C-219-15 Elisabeth Schmitt v. RÜV Rheinland LGA Products GmbH (2017) ECLI:EU:C:2017:128. 
ceived as part of a broader trend to subject private regulatory activities to fundamental principles of EU law and thus a 'constitutionalization' of private regulation. ${ }^{66}$

All these examples - however incomplete ${ }^{67}$ - illustrate one central point. We live in a multilayered legal order, in which the different layers relate not necessarily in a hierarchical order, but represent legal systems in their own right, each with their own conditions, consequences, sources and institutions for legislative and adjudicative tasks. National private law is therefore influenced by many sources, not always of national origin. Of course, this situation may create problems since the different layers are not always coherent. For this reason the different layers are connected in a variety of ways, such as the use of conflict rules pointing out which layer prevails, a dialogue between courts of the different systems such as the national courts and the ECJ or the ECHR, the principle of subsidiarity dictating the prominence of one of the systems, and the use of a margin of appreciation leaving opportunity for diversity in a uniform framework. The most important harmonizing factor is perhaps the interpretative labour of the courts, finding or constructing the applicable norm in each specific case by interpreting the applicable sources in a coherent way.

Taking the transnational dimension into account, we must now face the consequences for our understanding of the concept of private law. The positivist dimension is not restricted to sources of national private law, but encompasses international law (treatises), European law (EU law regulation, rulings of the ECJ), human rights law (the Convention, rulings of the ECHR), comparative law (for example, wrongful life cases), and so on and so forth. Again, these sources need not relate in a hierarchical order; they may constitute legal systems of their own, with their own conditions, consequences, members, institutions and sources. The same holds for the idealistic and the pragmatic dimensions. The values and principles of private law have both a broader origin and range than just national law, stemming from the Ius Commune with Roman roots and being effective in most Western private law systems. This may create normative dilemmas for courts and lawyers alike, balancing between parochialism (each system having its own values) and universalism (the same values hold everywhere). ${ }^{68}$ The wrongful life cases have illustrated that courts are increasingly inclined to take comparative law seriously. That

${ }_{66}$ Paul Verbruggen and Barend van Leeuwen, 'The liability of notified bodies under the EU's new approach: the implications of the PIP breasts implants case (C-219-15)' (2017) European Law Review, https://ssrn.com/abstract=3038830, accessed 23 March 2021 .

67 I have not even mentioned the treatises on private law, such as the Vienna Convention on Contracts for the International Sale of Goods (CISG).

68 Schiff Berman (n. 4) 61-141. 
means that they compare rulings from other systems without necessarily copying them. ${ }^{69}$ At the end of the day, the question is whether - and if so, to what extent - they represent existing practices and ways of life. In Israel and the Netherlands wrongful life claims were upheld; everywhere else they were rejected (albeit on diverging grounds). This may be a telling observation in the light of the ways of life in different legal cultures. ${ }^{70}$ Private law is embedded in a cultural context. As a consequence cultural norms and practices may exert their influence, to the effect that the same written norms may acquire an altogether different meaning. ${ }^{71}$ In our model of private law this is easy to understand: from a normative perspective they overlap, but from an idealistic and pragmatic viewpoint they diverge. Private law is simply not one-dimensional.

\subsection{THE CONCEPT OF PRIVATE LAW: ITS DOMAIN AND BORDERS}

Our exercise in mapping the territory of private law has shown that private law is a complex and multidimensional phenomenon. Although its hard core consists of rules and precedents regulating the legal relations between individuals, corporations and (state) agencies (A: the doctrinal dimension), it also encompasses values and principles (B: idealistic dimension), and unwritten law, customary rules and social norms (C: pragmatic dimension). The triangle model illustrates that private law covers a whole range of similar phenomena which are not easy to identify with one or more defining characteristics, varying from the Civil Code and European Directives to soft law, from judicial rulings to arbitration and mediation, and from legal principles to concepts like 'good faith' and 'duty of care'. The transnational dimension

69 Stephen Breyer has formulated it like this:

The second recurrent theme [of his book, next to the rule of law generally] is the need for courts to listen to what I might call 'many voices' ... I do not ignore the basic fact that the American people can and must democratically determine their own laws. But listening to those who understand the content of relevant foreign law is perfectly consistent with the democratic formulation and interpretation of our own law. See: Stephen Breyer, The Court and the World, American Law and Global Realities (New York: Albert A. Knopf, 2015) 7.

70 The examples may be multiplied with the recognition of same sex marriage, conflicts between religious obligations, the rights of indigenous people, and so on and so forth.

71 As I have experienced when working as a judge on the Caribbean island of Curaçao which - as a former Dutch colony - initially adopted the same civil code, but with completely different consequences in practice. Private law simply cannot be reduced to its doctrinal dimension, at least not without robbing it of its defining characteristics. 
has made us aware that we live in a multilayered legal system. Private law has other than national sources as well as a broader application than just within national borders. Figuratively speaking, one could say that the triangle is in fact duplicated in each legal system, which illustrates the complexity of its origins, validity and functioning. As a result private law is not characterized by one or more shared defining characteristics. It covers a whole field of connected but diverging meanings, so that one could characterize it as a 'family resemblance concept'. ${ }^{72}$ Its borders are vague, gradually declining into the domain of morality on the one hand, and into that of empirical practice on the other. Moreover, it is a 'fundamentally contested' concept since its borders are always contested..$^{73}$ Drawing the borders that mark the domain of private law is thus not just a scholarly act, to be conducted on objective grounds, it is itself an activity that rests on normative choices. This is illustrated by the Grand Old Theories of (private) law, each expressing a preference for the values of legal certainty, justice and efficacy respectively. Since there is no way to settle this controversy once and for all, it may be more fruitful to acknowledge that they all bring valuable insights, drawing our attention to the dimensions of private law that are at stake in different circumstances.

Again, this may be helpful in understanding the functioning of private law. The open gates between private law and morality on the one hand, and private law and effective power on the other, illustrate that the autonomy of private law is constantly in play. When private law is insufficiently responsive to societal needs and demands, it may become an isolated doctrine. There were times in history when legal formalism prevailed, and lawyers were technocrats (see Chapter 2). Autonomy prevailed over responsiveness, and private law gave bad service to society. Historically, this has always resulted in a contrary movement striving for a more realistic and responsive private law (see Chapter 2). Like a pendulum, the cyclical development, from formalism to realism and back, is one of the characteristic movements in private law doctrine. Private law may become be too ambitious, however, in striving for societal relevance and impact. The constant striving for responsiveness may undermine its autonomy, so that power or morality overrides private law. Huge corporations and other producers might dominate markets, for example, if consumers are not adequately protected by private law. The protection of the weak is one of the purposes of private law and this requires a strong and autonomous private law. ${ }^{74}$

72 The notion of 'family resemblance' is derived from Wittgenstein and will be explained in Chapter 3. In short, it signifies that the phenomena we characterize as private law do not share one or more common characteristics, but that they resemble one another like the members of a family.

73 The notion of 'fundamentally contested concepts' is derived from Waismann and will be explained in Chapter 3. In short, it means that the concept of private law cannot be used without bringing normative convictions into play.

${ }^{74}$ Philippe Nonet and Philip Selznick, Law and Society in Transition: Toward Responsive Law (New York: Harper \& Row, 1978). 
At the beginning of this chapter we distinguished and described two paradigms of legal scholarship, namely legal dogmatics and the functional social science approach (Section 1.2). As we observed, they each have a different understanding of private law. Now that we have seen more of the concept of private law, are we in a better position to assess this controversy? Taking the triangle model of private law seriously, we may be able to point to some shortcomings of both paradigms, and even try to pave the way for a legitimate middle ground.

First of all, legal dogmatics is too narrow if it is understood to be the positive frame of mind reducing private law to the rules and precedents that constitute its doctrinal dimension. When we include both its idealistic and its pragmatic dimensions, our analysis of private law is both enriched and more realistic. As we have seen, moral and pragmatic arguments are legitimate elements of private law reasoning, and thus part and parcel of its discourse. They show their faces more readily in hard cases such as the wrongful life cases but they are potentially always there, ready to participate if called upon. As the mixed theories of Radbruch, Dworkin and Fuller have learned, they can and should be integrated in our understanding of private law. As legal dogmatics may be too narrow, the functional social science approach, on the other hand, may be too broad. Reducing private law to a social technique, meant to serve some external goal such as social welfare, does not do justice to the autonomy of private law. Whatever the exact nature of private law, it is hard to deny that there is a connection to values and principles - even the master principle of justice itself - that renders it something more than just a social technique. Moreover, in some cases it may even be this undeniable moral dimension that makes private law less effective as a social technique. In the end, the analysis of the Law and Economics scholars - however fruitful in its own little corner - doesn't do justice to this dimension of private law.

Since neither paradigm is completely satisfactory, and private law seems to be multidimensional, it might be advisable to accept the inherent contextuality of private law, and thus the perspectivity of legal scholarship. By this we mean that our understanding of private law is always an understanding of private law in a certain context, or from a certain perspective, leaving other legitimate approaches unmentioned (for the time being). In the 'Introduction' we have already sketched what this contextualism amounts to. It is not legal dogmatics, although it recognizes the value of legal doctrine (as one of the dimensions of private law). It is neither social science functionalism, although it acknowledges the inherent societal function of private law (again, as one of its dimensions). It is not so much 'Law and ... (economics, sociology, 
psychology)' as 'Law as ... (all of these disciplines)' ${ }^{75}$ How did the wrongful life rulings fit into private law? What role did the moral and political decisions of the courts play in the answer to this question? How did they affect their interpretation of the law, and the other way around, how did their legal outlook influence their moral and political decisions? These questions relate to private law in its context, whatever context that may be in the case at hand. We started this chapter with the question: what is private law? We now end with the contextualist and perspectivist answer that it depends ... Hopefully we learned along the way why this is the case, and what it tells us about the nature of private law. Whatever other merits it may have, this middle ground between dogmatism and functionalism does in any case seem to do justice to the concept of private law.

75 James Boyd White, 'Doctrine in a vacuum', From Expectation to Experience, Essays on Law and Legal Education (Ann Arbor: The University of Michigan Press, 1999) 8-25. 